\title{
Control of molecular condition by ultrasonic vibration at constant electric field
}

\section{一定電界印加時における超音波振動による LB 分子配向制御}

\author{
Masaya IKEDA and Sadao UEGUSA \\ Department of Electrical Engineering,Tokai University, 1117 kitakaname, \\ hiratsuka kanagawa, 259-1292,Japan,TEL:+81-0463-58-1211(EXT.4162), FAX:81-0463-59-4014 \\ Tsutomu MIYASAKA \\ Material,Graduate School of Engineering,Toin University of Yokohama \\ 1614 Kurogane-cho,Aoba-ku,Yokohama,Kanagawa 225-8502,Japan \\ Kenichiro NAKAMURA \\ Department of Optical Engineering,Tokai University, 1117 Kitakaname,Hiratsuka,kanagawa, \\ 259-1292,Japan,TEL:+81-0463-58-1211 \\ Takanobu KUMAMOTO \\ Department of Chemistry, Tokai University,1117Kitakaname,Hiratsuka,kanagawa, \\ 259-1292,Japan, TEL:+81-0463-58-1211
}

( Received 15, November 2002 Accepted 20, January 2003 )

When the making of LB film with Merocyanine Dye, mixing of Arachidic acid stabilize the LB film.However, an electronic performance improves more by making only Merocyanine. Therefore, it is necessary to make the film stabilize onry in Merocyanine simple substance.For this purpose, the control technology of molecular condition was developed by electric field and ultrasonic vibration.Moreover, the state of controlled molecule was examined with the $\pi$-A curve.

Keywords:L/LBfilm,Controlled molecule condition, electric field, Ultrasonic vibration,Jband

\section{INTRODUCTION}

$\mathrm{p}$ 形半導体的特性を有するメロシアニン色素 (Merocyanine NK-2684:MC)を LB膜として製膜する 場合、アラキジン酸(Arachidic acid:AA)と混合するこ とにより、安定な製膜ができることが知られている。 しかし、AA は絶縁特性を有する分子であり、その混 合により電子機能性怟下することになる。したがっ て、この電子機能性を最大限に発揮させる分子の配向 条件は、MC分子単独で、かつ親水基が密着して並び、 㻋水基が規則的に傾いて配向した J 会合体(Jband)の 状態で製膜することである。このメロシアニンL B 膜 としてこの状態の膜が、最も優れた電子機能性を有す るであろうと考えられる。

メロシアニンの親・㻋水基間の分子双極子モーメン ト $\mu$ は、式(1)から 4.852debye と計算される。

$$
\mu=q \cdot 1
$$

これは水分子の 2 倍以上を有している。これにより、 水面上の単分膜を電界印加の下で製膜し、メロシアニ ン単独分子 LB 膜において J 会合体の存在を示す光吸 収ピークの確認に成功した。1

それは、電界印加で分子配向をさせていることの証 明になるが、J 会合体の吸収ピークそのものは混合膜 と比較し、上回ることができなかった。

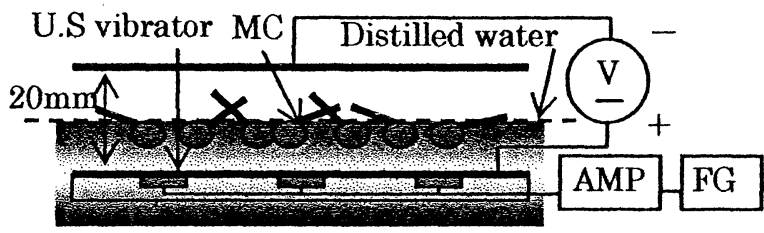

Fig.1. Controll system of LB.

そこで本稿では、新たに電界印加と超音波振動 (ultrasonic:U.S)による配向制御を考案した。すなわち、 超音波振動を加えることは、水面上の分子展開時の分 子凝集による島構造が原因となるL膜中のピンホール の解消、および柾水基どうしの絡みを解消可能と考え、 水面上 L膜の分子配向状態を $\pi$-A曲線から検討した。

\section{EXPRERIMENTAL}

Figure1 に示すように超音波振動子((株)トーキン製、 共振周波数 $50.6 \mathrm{kHz}$ )を有する箱状電極をLBトラフ水 面下に、またそれと平行な平板電極を空気中に配置し、 LB トラフ内の蒸留水面に MC 分子を展開した。その 後、任意の電界を印加後、ファンクションジェネレー 夕(FG)に接続した增幅器出力で超音波振動子を駆動 した。超音波振動を 60 秒間加えた後、両電源を切断 


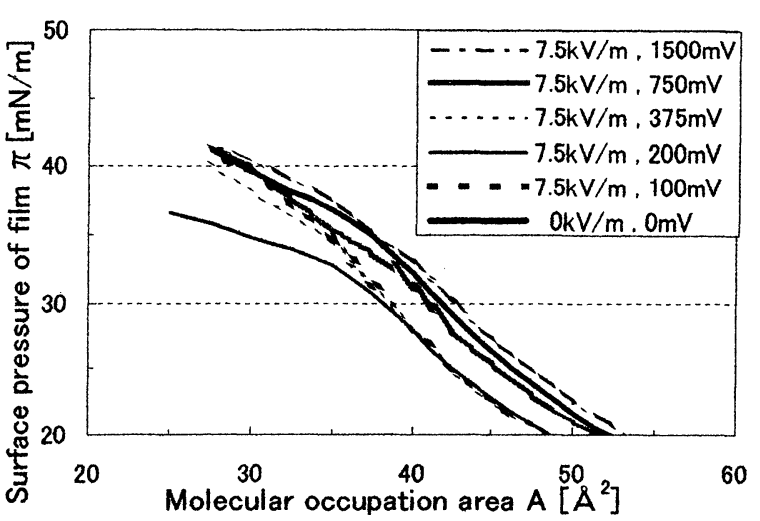

Fig.2. $\pi$-A curve of Merocyanine.

し、 $\pi$-A曲線を測定した。

実験パラメータは、印加電界を $\mathrm{E}=7.5 \mathrm{kV} / \mathrm{m}$ 一定とし、 超音波振動子に与える FG の出力電圧を $100,200,375$, 750 そして $1500 \mathrm{mV}$ とし $\pi$-A曲線を測定した。また その結果を、電界および超音波による制御なしの $\pi$ $\mathrm{A}$ 曲線と比較検尌した。

\section{RESULT}

水面上にメロシアニン分子を展開した場合、分子の 疎水基は一般に Fig.1 のように乱雑な方向を向き、疎 水基どうしが接触し、絡んでいる状態にあると考えら れる。この状態で表面圧を加えた場合、親水基どうし が離れた状態で圧縮され、同一表面圧での分子占有面 積が大きい状態で配向される可能性がある。

前節の実験方法に従った $\pi$-A 曲線の測定結果を Fig.2 に示す。同図から、配向制御しない場合と比較 し、FG 出力電圧 100,200 そして $375 \mathrm{mV}$ における同 一表面圧あたりの占有面積が低下した。また、FG 出 力 $1500 \mathrm{mV}$ においては逆に上昇の傾向を示した。

$\mathrm{FG}$ 出力 $750 \mathrm{mV}$ 以下の場合、水面の分子どおしの 絡み合いが超音波振動により開放されつつ、分子が両 電極間の電界で水面に対し垂直方向の配向トルクが与 えられた効果が生じたと考えられる。また、FG 出力 $100,200,375 \mathrm{mV}$ の場合は、同一表面圧 $\pi$ に対する占有 面積 $\mathrm{A}$ が、超音波振動なしの場合と比較し低下してい

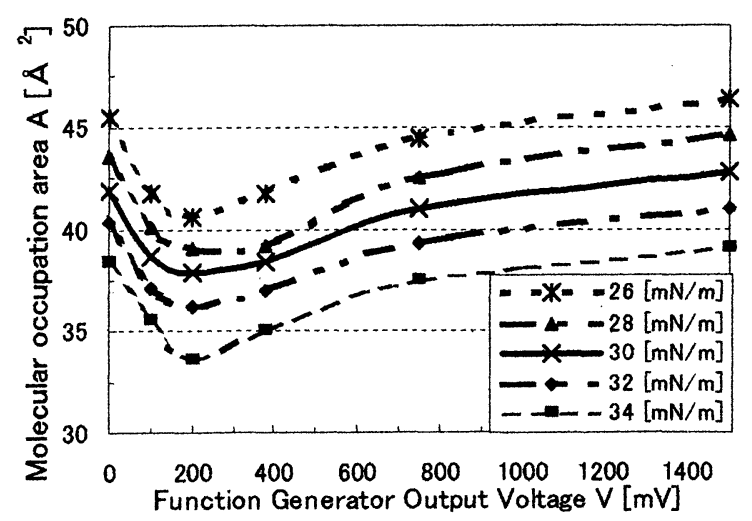

Fig.3. Molecule occupation area pressure of film.

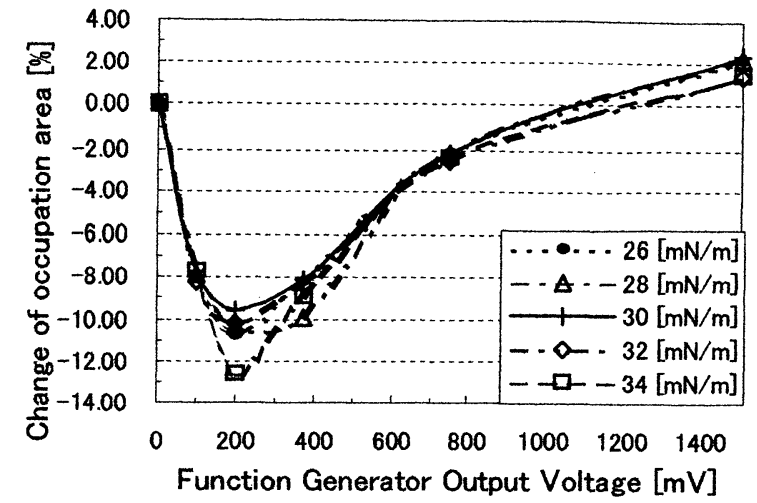

Fig.4. Increase and decrease pressure of film.

る。これは、分子に電界印加による配向トルクを加え つつ、超音波振動させることで、隣接部分どうしの疎 水基の絡み合いを解きつつ配向したと考えられる。

また逆に、FG 出力 $750,1500 \mathrm{mV}$ では、超音波振動 なしの場合と比較し、表面圧が上昇している。これは 分子に与える振動が電界による配向トルクを上回った ためと考えられる。すなわち、それにより水面上の分 子が混乱状態となり、隣接分子の疎水基どうしが超音 波振動なしの場合以上に接触し、絡み合っていること が考えられる。

Fig.3 は、Fig.2 を書き改め、同一表面圧における、 FG 出力に対する分子占有面積の関係を示す。さらに、 印加電界と FG 出力ゼ口の状態ける各表面圧の值を 0\%とした増減率を縌軸に示したのが Fig.4 である。

Fig.3 から、それぞれ分子配向制御をすることで、 同一表面圧における、平均分子占有面積が変化するこ とが明らかである。Fig.4 から、超音波なしの場合に 比べ、FG 出力 $200 \mathrm{mV}$ 付近で各曲線の極小点が存在す る。表面圧 $34 \mathrm{mN} / \mathrm{m}, \mathrm{FG}$ 出力 $200 \mathrm{mV}$ で最も低下し、 その減少率は約 $12 \%$ あった。

\section{IV.CONCLUSION}

本実験の結果から、以下の事項が明らかとなった。 （1）電界印加と水面の超音波振動による分子の配向制 御の結果、同一表面圧におけ分子占有面積が、無配 向制御時と比較し、最大 $12 \%$ の減少を見た。

（2）その原因の 1 つは、水面上の LB 分子に対し垂直 方向の電界印加は、分子の双極子モーメントに作用し、 分子の方向が電界方向に向からトルクを生じさせた。 （3）その 2 つ目は、水面に展開した LB 分子を超音波 振動させることにより、水面における分子凝集に起因 する L 膜のピンホールを解消させる働きをした。

\section{REFERENCE}

${ }^{1}$ T.Terao, Physical-properties analysis and molecule electric field control theory of an organic coloring-matter L/LB film. Master paper of Tokai University 2001 